\title{
CONTINUOUS MONITORING OF METAMORPHIC CHANGES OF INTERNAL SNOW STRUCTURE AS A TOOL IN AVALANCHE STUDIES
}

\author{
By Righard L. Armstrong \\ (Institute of Arctic and Alpine Research, University of Colorado, P.O. Box 456, Silverton, \\ Colorado 8i 433 , U.S.A.)
}

\begin{abstract}
Relationships between snow structure, climatic factors, and the nature of avalanche events in the San Juan Mountains of Colorado, U.S.A., are analyzed. Physical and mechanical properties of the snow cover have been monitored on a continuous basis by conventional methods as well as through the application of a profiling snow-density gauge. Temperature-gradient metamorphism is the dominant mechanism which determines the character of the local snow structure. Properties unique to well-developed temperature-gradient snow (depth hoar) are discussed. Three specific metamorphic processes are described which contribute to a highly varied and mechanically weak snow structure. Analysis of fracture-line profile data allow general studies of the local snow climate to be compared with the stratigraphy of actual release zones. Fracture-line data support the conclusion that meteorological conditions prevailing at the time of new-snow deposition play a less significant role in the eventual release of slab avalanches than metamorphic processes which influence the snow cover between storm periods. Shear failure zones are consistently composed of weak layers metamorphosed weeks and even months prior to the precipitation event which triggers the release.
\end{abstract}

RÉsUMÉ. La prévision continue des métamorphoses internes de la structure de la neige : un outil pour les études d'avalanche. On a analysé, dans les Montagnes de San Juan au Colorado (U.S.A.), les relations entre la structure de la neige, les fracteurs du climat et la nature des avalanches observées. Les propriétés physiques et mécaniques du manteau neigeux ont été reconstituées de manière continue, par les méthodes conventionnelles ainsi qu'à partir d'une sonde à neige exécutant des profils densimétriques. La métamorphose due au gradient thermique est le mécanisme dominant qui détermine le caractère de la structure locale du manteau neigeux. Les propriétés très particulières de la neige de gradient thermique bien développée (givre de profondeur) sont discutées. Trois processus de métamorphoses sont décrits qui contribuent à des structures de neige extrêmement variables et mécaniquement peu résistantes.

Les analyses de profils à la ligne de rupture permettent la comparaison entre les études générales du climat neigeux et la stratigraphie des zones de déclenchement réelles. Les données recueillies sur les lignes de rupture permettent de conclure que les conditions météorologiques régnant au moment des chutes de neige fraîche jouent un moindre rôle dans les départs éventuels d'avalanches de plaque que les métamorphoses qui se produisent dans le manteau neigeux entre les épisodes de précipitations, les zones de rupture du cisaillement, sont, de manière constante, constituées par des niveaux de faible résistance dont la métamorphose remonte à des semaines et même des mois avant les précipitations qui provoquent le déclenchement de l'avalanche.

Zusammenfassung. Kontinuierliche Beobachtung der Metamorphose des inneren Schneegefüges als Hilfsmittel der Lawinenforschung. Der Zusammenhang zwischen Schneegefüge, Klimafaktoren und Art der Lawinenabgänge in den San Juan Mountains von Colorado, U.S.A., wird untersucht. Physikalische und mechanische Eigenschaften der Schneedecke wurden sowohl mit konventionellen Methoden wie unter Verwendung einer Schneedichtesonde kontinuierlich beobachtet. Die Metamorphose infolge des Temperaturgradienten erweist sich als der für den Charakter des lokalen Schneegefüges ausschlaggebende Mechanismus. Eigenschaften, die für Schnee mit gut entwickeltem Temperaturgradient (Tiefenreif) bezeichnend sind, werden diskutiert. Drei spezifische Metamorphose-Vorgänge lassen sich feststellen, die zur Ausbildung eines hoch differenzierten und mechanisch schwachen Schneegefüges führen. Die Analyse von Abrissprofilen ermöglicht den Vergleich von allgemeinen Studien des lokalen Schneeklimas mit der Stratigraphie der tatsächlichen Auslösungszone. Solche Daten stützen die Annahme, dass die Witterungsverhältnisse während eines Neuschneefalles für den eventuellen Abgang eines Schneebrettes weniger bedeutungsvoll sind als die Vorgänge, welche die Schneedecke zwischen Schlectwetterperioden verändern. Scherbruchzonen bestehen überwiegend aus schwachen Schichten, die sich Wochen oder sogar Monate vor dem Schneefall, der den Abgang auslöst, gebildet haben.

\section{INTRODUCTION}

Data providing the basis for avalanche release prediction are available from two sources: direct examination of the mechanical properties of the snow structure in question, and analysis of meteorological data. Meteorological evidence can be relied on more heavily when prediction involves avalanches which release primarily as a result of instability within newly fallen snow. Such conditions exist within the mountain ranges of the Pacific Coast of the United States where deep and stable snow covers predominate (LaChapelle, i966). 
Direct snow-cover data are required when the avalanche is caused primarily by weak layers that have developed within the old snow cover. However, because meteorological instrumentation is more adequately developed than that necessary to obtain snow-structure parameters on a continuous basis, emphasis may often be placed on meteorological data in situations where snow structure would provide more valuable information.

The highway network within the San Juan Mountains is subject to one of the highest levels of snow-avalanche activity in the United States. Studies regarding the nature and causes of avalanches and historic recurrence intervals within this area were undertaken by the Institute of Arctic and Alpine Research (INSTAAR), University of Colorado (Armstrong and Ives, 1976; Armstrong, 1976, p. 34). Initial work on avalanche event prediction showed a good correlation between precipitation factors and avalanche frequency, but a poor relationship when event magnitude was considered. From these studies it became apparent that a thorough understanding of local avalanche formation would depend heavily upon a detailed knowledge of the specific character of the snow structure, as well as upon meteorological parameters.

\section{Methods OF SNOW-STRUCTURE ANALYSIS}

Stratigraphic investigations were undertaken at the primary snow-study site on Red Mountain Pass ( $3400 \mathrm{~m})$ as well as on surrounding test slopes or potential avalanche-release zones with elevations and orientations comparable to active avalanche-release zones. Such studies were acquired as a series at fixed sites to determine changes in snow structure with time. A third type of snow-pit study was undertaken at actual avalanche fracture lines.

In addition to conventional methods, stratigraphic data were obtained through the application of a profiling snow gauge which provides in situ density values at $1.0 \mathrm{~cm}$ intervals by means of gamma-ray attenuation. This instrument allows continuous non-destructive density measurements within the same stratigraphic sample, providing a progressive record from new-snow deposition through the respective stages of metamorphism.

Three winter seasons of field investigations led to a comprehensive definition of the local snow climate (LaChapelle, 1974, p. I 40). Slopes with a northerly aspect and steeper than $30^{\circ}$ receive little solar radiation during winter and experience persistent strong radiation cooling. Total snow depths are not great (1.0-3.0 m), nor are storm increments, which rarely exceed $30 \mathrm{~cm}$. Optimum conditions thus exist for extreme temperature differences between the ground, consistently at or near $0.0^{\circ} \mathrm{C}$, and the low temperatures at the snow surface above. Vapor transfer occurring along the temperature gradient results in the formation of large, loosely packed crystals or depth hoar. Temperature-gradient metamorphism dominates snow structure genesis on southerly slopes as well, with vapor-pressure gradients often exceeding those measured on north-facing slopes due to higher mean snow-cover temperatures, combined with comparable temperature gradients. Little stabilization, often associated with substantial solar energy, occurs even on south-facing slopes. While the mean internal temperature gradients of north- and south-facing slopes do not differ to a significant extent, such values being a function of long-term mean daily air temperatures, it is within the near-surface layers that the radical contrast exists. At the altitude $(3400-3900 \mathrm{~m})$ and latitude $\left(37^{\circ} \mathrm{N}\right.$.) of the study area, southerly slopes experience extreme diurnal fluctuations in the radiationdetermined temperature of the near-surface layers. This condition continues throughout the winter and a highly complex stratigraphy develops, characterized by large variations in structure and strength. Layers of relatively homogeneous, stronger snow, comprising the individual precipitation increments, are separated by thin layers of temperature-gradient snow and freeze-thaw crusts that have developed during clear-weather periods between storms. Poor layer bonding is prevalent in these situations and the snow cover can be described as conditionally unstable. By this it is meant that at any given time while the snow 
cover is at sub-freezing temperatures, it is only marginally unstable with respect to spontaneous slab release due to internal causes, but remains throughout each winter highly susceptible to load-induced avalanche release.

\section{RELATIONSHIP BETWEEN AVALANCHE RELEASE AND SNOW STRUCTURE}

Initial investigation indicated that over $90 \%$ of the mid-winter avalanches within the study area occurred during storm periods. Delayed-action events were rare. Good statistical relationships between avalanche events and meteorological conditions, primarily precipitation factors, could be established (Bovis, 1977). However, inconsistencies appeared when the magnitude and type of avalanche were related to precipitation factors alone. Periods of significant precipitation and wind transport might in one case produce large slab releases, while the same meteorological conditions at another time might produce little or no avalanche activity. Conversely, relatively small amounts of precipitation sometimes resulted in widespread and deep slab releases.

The basic pattern of avalanche release mechanics has been consistent during the study period. Of the fracture-line studies, over $85 \%$ exhibited a climax avalanche structure (slab failure occurred in older snow layers deposited and metamorphosed prior to the triggering event). In $75 \%$ of the cases investigated, the lubricating layer beneath the slab was identified as recrystallized snow resulting from temperature-gradient processes.

If snow structure actually controlled the type and depth of avalanche release, a pattern should emerge if snow structure conditions were monitored throughout the avalanche season. An example of this type of analysis is found in Figures I and 2. Figure I shows the typically poor relationship between avalanche events and the total precipitation (millimeters of water equivalent) comprising each discrete storm period. The linear regression $r$-value for Figure I is only 0.08 . However, when the season is divided into four time periods, the precipitation and avalanche event data tend to conform to a systematic pattern (Fig. 2). The periods are subdivided by date based on the best four chronological regression groupings. Mean snow-cover temperature-gradient values for each period, as measured at the Red Mountain Pass study

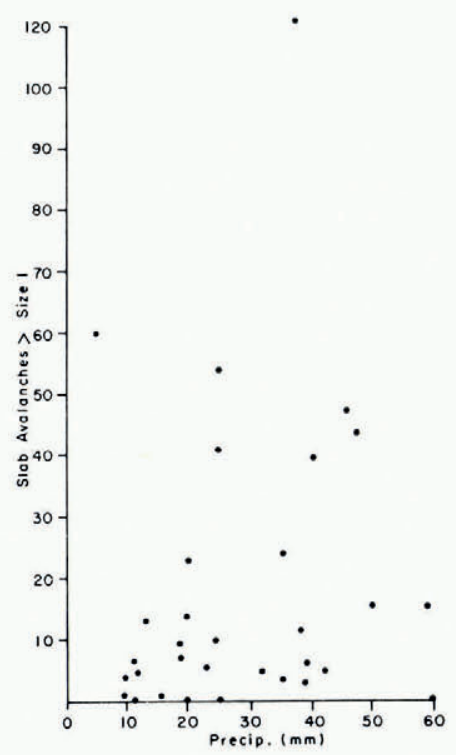

Fig. I. Relationship between individual storm precipitation totals (mm water equivalent) and number of observed slab avalanches larger than size one during the 1974-75 winter. 


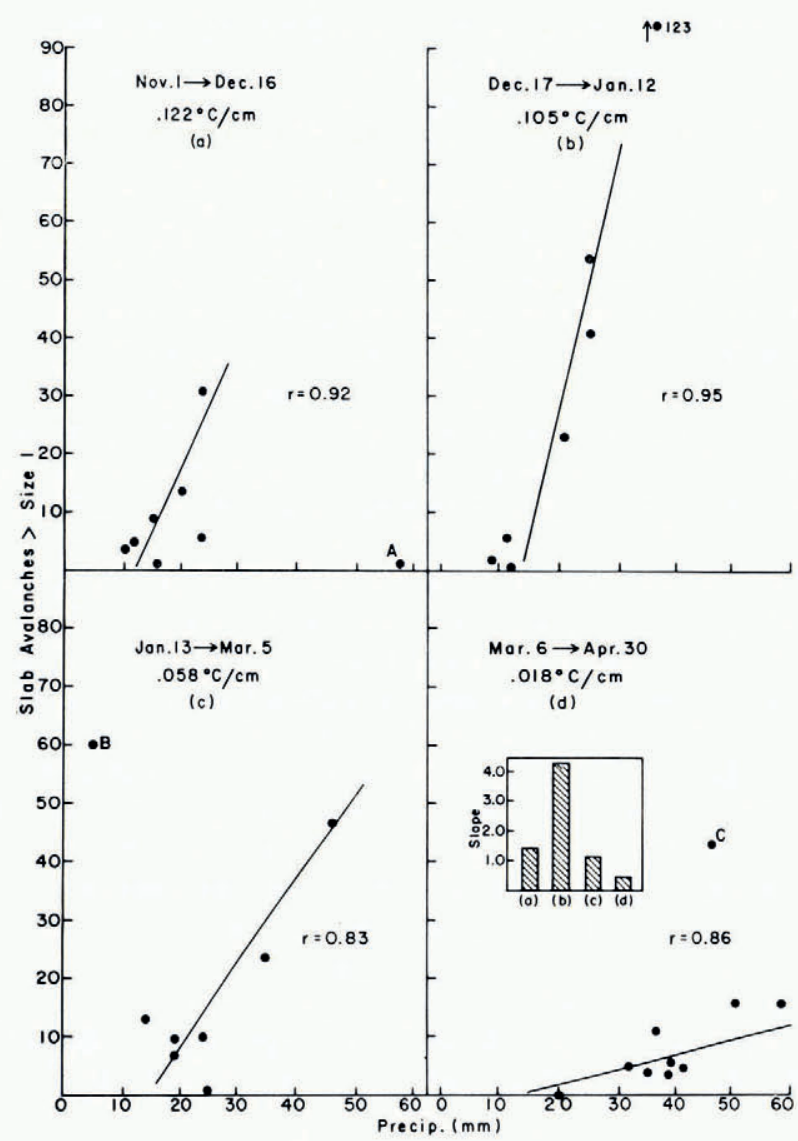

Fig. 2. Relationship between individual storm precipitation totals and number of observed slab avalanches larger than size one subdivided into four periods according to progressive changes in snow structure for the $1974^{-75}$ winter.

site, are provided as an additional index of snow-cover conditions. These mean temperature gradients appear below the appropriate dates in Figure 2. Linear regression $r$-values appear for each of the four time periods and the relative instability of the snow structure associated with each period is depicted by the slope value for the appropriate avalanche-precipitation relationship (inset in Fig. 2d). The period I November to I6 December indicates the steepest temperature gradient and while the general snow structure is weakening in response to this condition, it is not until the period 17 December to 12 January that the weakness attains a maximum, creating a pattern where large numbers of avalanches result from relatively small amounts of precipitation. The period 13 January to 5 March represents a period of transition with the snow cover gaining strength as the temperature gradient decreases. The final period represents the snow cover as it approaches an isothermal condition.

The deviation of data points $\mathrm{A}$ in Figure $2 \mathrm{a}$, $\mathrm{B}$ in Figure $2 \mathrm{c}$ and $\mathrm{c}$ in Figure $2 \mathrm{~d}$ were not included in the regression analysis and can be dealt with as individual cases based on the following supplemental data: Point A represents an early precipitation episode when new snow was accumulating on bare ground or shallow old snow. In case B, 23 February i975, although little direct precipitation was recorded, additional loading did occur as the result of a wind-transport episode with a duration of $18 \mathrm{~h}$ and a mean wind speed of $13 \mathrm{~m} / \mathrm{s}$. Case c, I3 April i975, occurred when numerous, small, soft slab events occurred within the new snow. 
During the last $12 \mathrm{~d}$ preceeding this cycle, $95 \mathrm{~mm}$ of precipitation had been recorded at the Red Mountain Pass study site without significant avalanche activity. The structural regime represented by Figure $2 \mathrm{~d}$ is that of new snow collecting on an exceedingly stable, nearisothermal snow cover. Failure within the older snow structure was therefore precluded and a shear failure plane developed in conjunction with a freeze-thaw crust that was established during a brief clear-weather episode within the longer period of heavy precipitation. This cycle is an isolated example of slab release within new snow, an avalanche pattern which frequently occurs in climates where stable old-snow structure prevails, but is the exception within the San Juan snow climate.

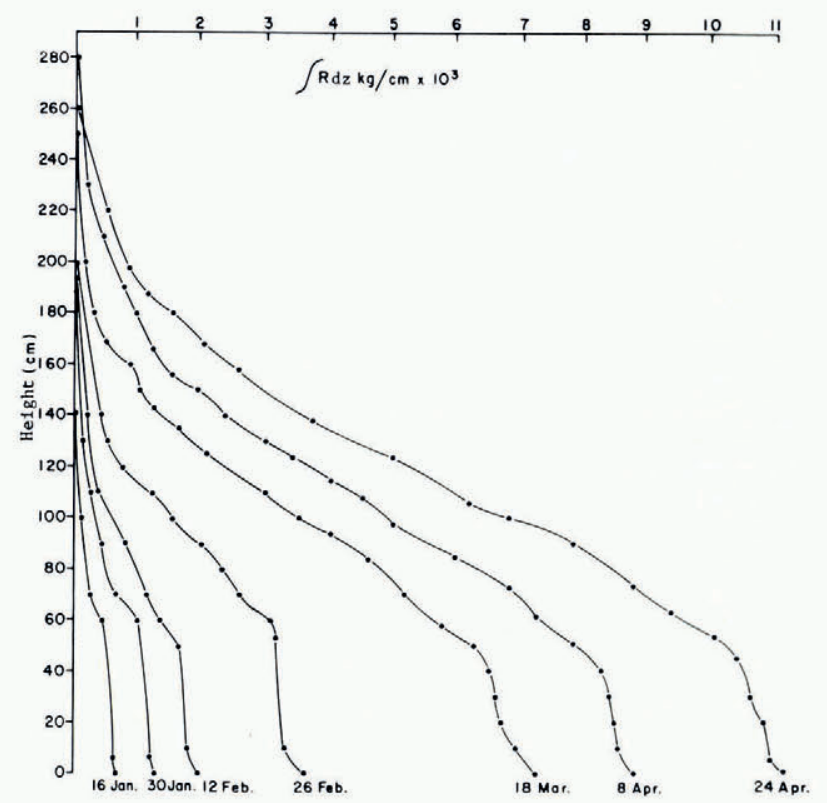

Fig. 3. Integrated rammsonde resistance curves for seven selected dates at the Red Mountain Pass study site during the $1974-75$ winter.

Having established that snow structure may exhibit significant control over the nature of avalanche release, what then are the physical conditions which create such a stratigraphy? There appear to be three distinct situations: a substantially thick layer of temperaturegradient snow or depth hoar at the base of the snow cover, alternating layers of melt-freeze crusts and temperature-gradient snow, and instability resulting from restricted consolidation of near-surface snow layers. Once a substantial basal layer of mechanically weak depth hoar has formed within a release zone, only a significant avalanche cycle can eliminate this condition. Minimal intergranular bonding prevails and even as the depth and thus load of the overlying snow cover increases as the winter progresses, and the initial steep temperature gradient is diminished, either due to increasing snow depth or increasing air temperatures of late winter and early spring or both, only minimal improvement in intergranular cohesion occurs. Figure 3 shows the increase in rammsonde resistance with depth within the mid-pack layers followed by the sharp break in this relationship as the lower depth-hoar layers are reached. Figure 4 shows the limited densification with time of the depth-hoar layer (from o-6o cm) compared to the layers above, which were exposed to less steep temperature gradients. Figure 5 demonstrates the resistance to settlement exhibited by well-advanced temperature-gradient snow (settlement curve $\mathrm{I}$ ). Curves 2 through 4 represent the settlement 


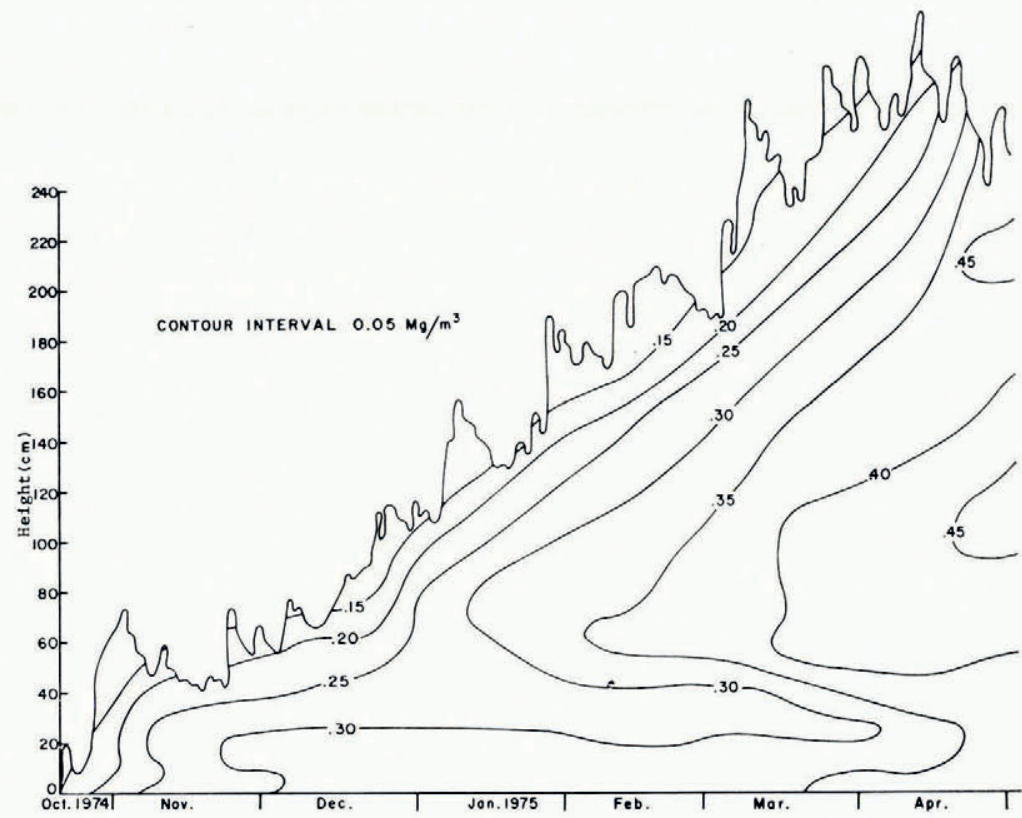

Fig. 4. A time-stratigraphic diagram of density variations $\left(\mathrm{Mg} / \mathrm{m}^{3}\right)$ at the Red Mountain Pass study site for the period I5 October 1974 through 30 April 1975.

rate of snow layers deposited during mid-winter and exposed to a lesser temperature gradient (o.o8 to $0.15 \mathrm{deg} / \mathrm{cm})$. Curves 5 through 7 represent the settlement of snow layers at or very near an isothermal condition ( 0.02 to $0.07 \mathrm{deg} / \mathrm{cm})$.

If in a given release zone the basal depth-hoar layer is not removed by mid-winter avalanching, it may provide a structure which increases the probability of wet-slab avalanches in the spring. As percolating melt water comes in contact with a snow cover which has been developing over several months, optimum shear boundary conditions are created for slab-type releases. In contrast to this situation, a winter with frequent, deep avalanching results in the removal of a major portion of the snow cover metamorphosed under early to mid-winter conditions. Subsequent snowfalls in late winter and early spring are exposed to less significant temperature-gradient metamorphism and thus comprise a more homogeneous and stable structure.

The second type of weak layer results from alternating melt-freeze crusts and recrystallized snow. All slopes excepting those with a northerly exposure have been observed to experience subsurface warming due to the penetration and absorption of solar radiation. At any time during the winter season this warming can be sufficient to cause the snow temperature to reach the melting point with the eventual formation of a melt-freeze crust. This phenomenon has been observed by Yosida (1960). Even at the warmest point in the diurnal temperature cycle, when melt is occurring $1.0-3.0 \mathrm{~cm}$ beneath the surface, the temperature of the snowair interface, due to radiation cooling, may remain several degrees below freezing, creating an extremely steep temperature gradient across the uppermost several millimeters of the snow cover. This combination provides optimum conditions for temperature-gradient recrystallization; mean snow temperatures at or near freezing providing maximum vapor supply, a snow layer of low density allowing maximum vapor diffusion, and a temperature gradient as high as several degrees per centimeter. Vapor-pressure gradients within these surface layers may commonly be as high as 0.60 to $0.80 \mathrm{mbar} / \mathrm{cm}$, values which are as much 


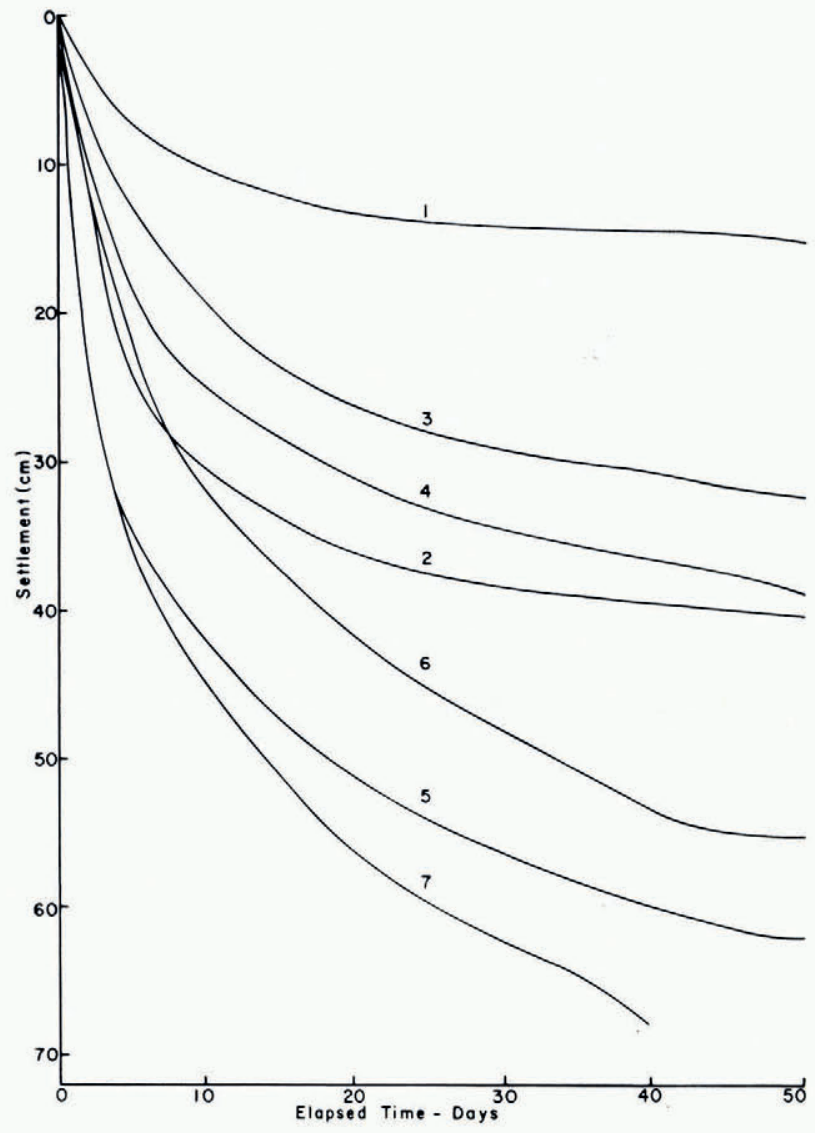

Fig. 5. Initial settlement rates at seven points within the snow cover at the Red Mountain Pass study site, 1974-75. Number I is representative of the early winter snow cover, numbers 2 through 4 are mid-winter and 5 through! $7{ }^{\prime}$ are early spring conditions.

as ten times greater than those considered adequate to initiate temperature-gradient metamorphism (LaChapelle and Armstrong, in press). Consequently, advanced temperaturegradient recrystallization may occur within $24 \mathrm{~h}$. This process has been called "radiation recrystallization" by LaChapelle (1970) and has been frequently observed in the San Juan Mountains. Initially created near the surface of the snow cover, the recrystallized layer is buried by subsequent snowfalls and provides an ideal lubricating layer. Beneath the recrystallized layer, the refrozen thaw layer provides a sliding surface. In this situation, poor adhesion between the slab and the sliding surface appears to contribute towards the failure, rather than a separate and distinct weak layer of substantial thickness. Figure 6 contains an example of this type of stratigraphy as it has developed through mid-winter. Figure 7 shows the relationship between calculated shear stress of the slab and measured density of the lubricating layer below. Density samples were limited to average values across 50 mm layers, whereas the actual shear failure zone may often have been less than $10 \mathrm{~mm}$ in thickness.

The third condition creating a weak layer is caused by retarded settlement of near-surface snow layers due to low temperatures $\left(-15.0\right.$ to $-25.0^{\circ} \mathrm{C}$ ) as well as minimal overburden pressure. Low-density shallow snowfalls are common to this area with the average storm depth being $17 \mathrm{~cm}$ and an average mid-winter density of $0.065 \mathrm{Mg} / \mathrm{m}^{3}$. This situation differs 


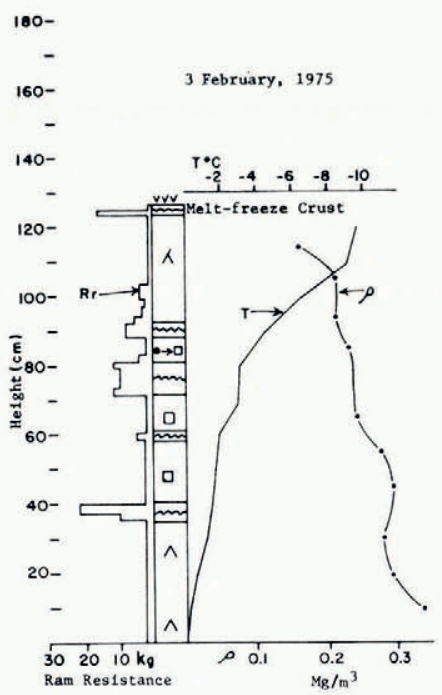

Fig. 6. Stratigraphic snow-cover data typical of a south-facing slope during mid-winter in the San fuan Mountains showing alternating layers of melt-freeze crusts and recrystallized temperature-gradient snow.

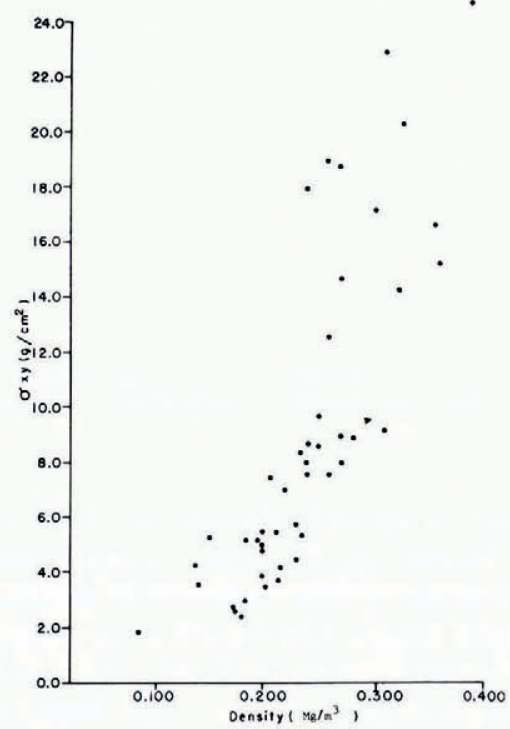

Fig. 7. Relationship between calculated slab shear stress at the point of failure (fracture line) and the measured density of the lubricating layer at the base of the slab.

from climates where snowfall amounts are greater and snow and air temperatures are consistently closer to freezing. Relationships between overburden pressure, temperature and layer densification have been analyzed elsewhere (de Quervain, I958; Kojima, [1975]) with the unconsolidated and shallow temperature-gradient layers showing minimal or no increase in density or strength with time. Only substantial loading caused strength increases but in terms of avalanching, shear failure may well occur beforehand.

The first two conditions which result in the formation of weak layers are directly controlled by temperature-gradient metamorphism and while the third is initially related to meteoro- 
logical conditions during precipitation periods, it is the subsequent clear-sky radiational cooling which establishes steep temperature gradients and preserves the unconsolidated structure of the layers. Under compressive bulk stress, snow commonly densifies, creates new bonds and increases in mechanical strength with time. However, temperature-gradient snow does not behave in this fashion. Studies conducted by de Quervain (1958) and Akitaya (1974) have indicated that while temperature-gradient snow is quite weak in shear, it retains a relatively high compressive viscosity, and once the initial changes associated with surfaccfree energy adjustments in the new snow are accomplished, temperature-gradient metamorphism tends severely to inhibit the densification process and thus any associated gain in shear strength. The cumulative loading of new snow above these temperature-gradient layers causes them to densify only slightly compared to layers which experienced initial metamorphism under less steep temperature gradients. Even as temperature gradients become minimal $(0.05 \mathrm{deg} / \mathrm{cm})$ across a layer of well-developed, coarse-grained temperaturegradient crystals, only minor increases in shear strength occur, partially because shear strength in a coarse granular material is inversely proportional to grain size and also because the larger grains have fewer physical opportunities for bond growth once a lesser gradient allowing the growth prevails.

\section{Conclusion}

The ability accurately to predict the location and magnitude of avalanche events in the San Juan Mountains of Colorado is heavily dependent on a thorough knowledge of the local snow structure. Meteorological conditions prevailing at the time of new-snow deposition play a less significant role in the eventual release of deep slabs and even the physical properties of the new snow itself are less important than the specific metamorphic processes which occur between storm periods. The stratigraphy of the snow cover is essentially determined by physical conditions at or within a few centimeters of the snow surface as solar heating and radiation cooling respectively alter the new-snow structure. The dominant metamorphic processes involve recrystallization along vapor-pressure gradients and melt-freeze cycles. The strong influence of solar radiation causes significant structural variation according to slope orientation. The physical properties of the surface snow layers remain virtually unchanged as they are incorporated into the snow-pack by subsequent snowfalls. The resultant stratigraphy is highly varied and mechanically weak.

Evidence suggests that avalanche release within sub-freezing snow is primarily dependent on precipitation to trigger unstable layers deep within the snow cover. However, the snow structure that exists at the time the precipitation-loading event occurs determines the nature of the snow failure. Fracture-line profile data indicate that $85 \%$ of the shear failure planes are located within older snow layers metamorphosed days if not months prior to the triggering precipitation event. Avalanche magnitude is further affected by the mechanical strength of all snow layers within the track, for this determines the penetration depth of sliding snow and the ultimate volume of the moving avalanche. All unstable snow layers remain as potential zones of failure until removed by avalanche activity or by melting in place. Continuous monitoring of snow structure metamorphism, especially in early winter, is essential to a thorough understanding of the relationship, unique within each winter season, between slope loading by precipitation and the nature of subsequent avalanche releases.

\section{Acknowledgements}

The support for this research has been provided by the Division of Atmospheric Water Resources Management, U.S. Bureau of Reclamation, and the U.S. Army Research Office. The author gratefully acknowledges tile guidance and suggestions provided by Drs E. R. LaChapelle and M. Mellor. 


\section{REFERENCES}

Akitaya, E. 1974. Studies on depth hoar. Contributions from the Institute of Low Temperature Science, Hokkaido University, Ser. A, No. 26.

Armstrong, B. R. 1976. Century of struggle against snow: a history of avalanche hazard in San Juan County, Colorado. University of Colorado. Institute of Arctic and Alpine Research. Occasional Paper No. 18.

Armstrong, R. L., and Ives, J. D., ed. 1976. Avalanche release and snow characteristics, San Juan Mountains, Colorado. University of Colorado. Institute of Arctic and Alpine Research. Occasional Paper No. I9.

Bovis, M. J. 1977. Statistical forecasting of snow avalanches, San Juan Mountains, southern Colorado, U.S.A. fournal of Glaciology, Vol. 18 , No. 78, p. 87-99.

Kojima, K. [1975.] A field experiment on the rate of densification of natural snow layers under low stresses. [Union Géodésique et Géophysique Internationale. Association Internationale des Sciences Hydrologiques. Commission des Neiges et Glaces.] Symposium. Mécanique de la neige. Actes du colloque de Grindelwald, avril 1974, p. $298-308$. (IAHS-AISH Publication No. 114 .)

LaChapelle, E. R. 1966 . Avalanche forecasting - a modern synthesis. Union de Géodésie et Géophysique Internationale. Association Internationale d'Hydrologie Scientifique. Commission pour la Neige et la Glace. Division Neige Saisonnière et Avalanches. Symposium international sur les aspects scientifiques des avalanches de neige, 5-10 avril 1965, Davos, Suisse, p. 350-56. (Publication No. 69 de l'Association Internationale d'Hydrologie Scientifique.)

LaChapelle, E. R. 1970. Principles of avalanche forecasting. Canada. National Research Council. Associate Committee on Geotechnical Research. Technical Memorandum No. 98, p. 106-13.

LaChapelle, E. R. 1974. Physical causes of avalanches in the San Juan Mountains. University of Colorado. Institute of Arctic and Alpine Research. Occasional Paper No. 13, p. 31-40.

LaChapelle, E. R., and Armstrong, R. L. In press. Snowcover, temperature and metamorphism patterns in the San Juan Mountains of southwestern Colorado. University of Colorado. Institute of Arctic and Alpine Research. Occasional Paper.

Quervain, M. R. de. 1958. On metamorphism and hardening of snow under constant pressure and temperature gradient. Union Géodésique et Géophysique Internationale. Association Internationale d'Hydrologie Scientifique. Assemblée générale de Toronto, 3-14 sept. 1957, Tom. 4, p. 225-39. (Publication No. 46 de l'Association Internationale d'Hydrologie Scientifique.)

Yosida, Z. [i.e. Yoshida, J.] 196o. Nissha ni yoru sekisetsu no naibu yūkai [Internal melting of snow due to the penetrating sunlight]. Teion-kagaku: Low Temperature Science, Ser. A, [No. 9], p. 97-1 10. 